\title{
Survey on Incidence of Dry Root Rot of Sweet Orange in Aurangabad and Jalna District of Marathwada Region, India
}

\author{
S.A. Padvi ${ }^{1 *}$, P.B. Khaire ${ }^{2}$, V.H. Bhagat ${ }^{2}$ and D.G. Hingole ${ }^{1}$ \\ ${ }^{1}$ Department of Plant Pathology, College of Agriculture, Badnapur, 431202 (M.S), India \\ ${ }^{2}$ College of Agriculture Naigaon (Bz.), Nanded, 431709 (M.S), India
}

*Corresponding author

\begin{tabular}{|c|c|}
\hline & A B S T R A C T \\
\hline Keywords & \multirow{4}{*}{$\begin{array}{l}\text { Dry root rot (Fusarium solani) is the major fungal disease affecting both life span and } \\
\text { production of sweet orange. The survey revealed incidence of dry root rot in the range of } 5 \\
\text { to } 50 \% \text { and nearly } 10 \text { to } 15 \% \text { trees were killed every year. In Jalna district, average } \\
\text { incidence of dry root rot was } 20.49 \% \text {. However, it was maximum in Jalna and tehsil } \\
(24.91 \%) \text {, followed by Mantha }(24.23 \%) \text {, Badnapur ( } 22.60 \%) \text {, Jafrabad (19.54\%), Ambad } \\
(19.36 \%) \text {, Bhokardan }(19.60 \%) \text {, and Partur }(17.93 \%) \text {. In Aurangabad district average } \\
\text { incidence of dry root rot was } 16.84 \% \text {. However, it was maximum in Aurangabad } \\
(21.92 \%) \text {, followed by Soyegaon }(21.20) \text {, Gangapur (19.54\%), Kannd (19.00\%), Paithan } \\
(15.73 \%) \text {, Vaijapur (14.14\%), Phulambri }(13.20 \%) \text { and Kulthabad }(14.12 \%) \text {. The lowest } \\
\text { disease incidence was reported in Sillod tashil. }\end{array}$} \\
\hline $\begin{array}{l}\text { Incidence, Dry root } \\
\text { rot, Sweet orange }\end{array}$ & \\
\hline Article Info & \\
\hline $\begin{array}{l}\text { Accepted: } \\
\text { 26 June } 2018 \\
\text { Available Online: } \\
\text { 10 July } 2018\end{array}$ & \\
\hline
\end{tabular}

\section{Introduction}

Sweet orange is one of the most important tropical fruit crop of the world and in India, it is most commercially grown fruit crop. Its cultivation in Marathwada region is facing numerous production constraints including diseases caused by fungi, bacteria and viruses. Dry root rot (Fusarium solani) is the major fungal disease affecting both life span and production of sweet orange. Dry root rot of citrus has been reported from California, Australia, and South Africa, usually for trees on trifoliate citrus or citrange rootstocks (Broadbent 2000). Apparently healthy trees suddenly wilt and die, and the roots are blackened and rotted with a brown, vascular discoloration within the stem of the rootstock. In Florida, similar decline symptoms occur with trees affected by blight and tangerine collapse, both with unknown etiologies (Graham et al., 1985). Various fungi have been isolated from trees affected with dry root rot, including Coprinus micaceus and Diaporthe citri, but Fusarium solani, a ubiquitous fungus with varying pathogenicity to citrus under stress conditions, can also induce dry root rot (Broadbent 2000). F. solani has also been isolated from affected citrus in Florida, and can cause root necrosis in trifoliate orange seedlings having depleted starch reserves. However, this fungus is not believed to be the primary cause of blight, 
which is considered to differ from tangerine collapse (Graham et al., 1985). Dry root rot has not been reported previously in Texas, where most trees are grafted on sour orange rootstocks. However, the recovery of Fusarium spp. from both healthy and dead grapefruit twigs has been reported (Okamura and Davis 1987). This paper reports on the results of incidence of the pathogen.

\section{Materials and Methods}

\section{Survey of dry root rot of sweet orange}

Keeping in view of the importance of sweet orange dry root rot a fix plot roving survey was carried out in the farmers orchards and nurseries for the recording prevalence of disease in Jalna and Aurangabad districts of Marathwada region during rabbi season of 2015-2016 Location were surveyed for each orchard/ nursery.

The incidence of disease was recorded by counting total number of plants and infected plants in each location and per cent disease incidence was determined by using a formula per cent disease incidence of dry root rot of sweet orange was calculated by using formula.

Per cent Disease Incidence $=$

Number of plants infected

Total number of plants examined

\section{Results and Discussion}

Survey on incidence of dry root rot of sweet orange in Aurangabad and Jalna district of Marathwada region.

For recording the prevalence and distribution of dry root rot of Sweet orange caused by Fusarium solani. An extensive survey was undertaken in different 52 orchards main field and 10 nurseries of Aurangabad and Jalna districts.

\section{At nursery stage}

The data presented in Table 1 showed that prevalence incidence of dry root rot of Sweet orange at in all the surveyed in Jalna and Aurangabad districts. In Jalna district the disease incidence was ranged from 9.00 to 15.8 per cent. However, the maximum disease incidence of dry root rot was found in Godavari nursery $(15.80 \%)$, at Krushiraj fruit nursery, Nagik Pangari. This was followed by the Govt. Nursery, Wadigodari (12.30\%), Govt. Taluka Fruit nursery, Mantha (11.33\%), Govt. Nursery, Jalna (10.50\%) and Taluka fruit nursery, Badnapur $(9.00 \%)$.

The disease incidence of dry root rot in Aurangabad district at nursery stage i.e. at seedling stage reported varied from 07.22 per cent to 13.00 per cent. However, the highest per cent disease incidence was found in Gajanan fruit nursery, Pimpariraja $(13.00 \%)$.This was followed by Mohini fruit nursery, Aurangabad (12.62\%), Govt. fruit nursery, Sillod (10.55\%), Deepak fruit nursery, Adul (09.44 \%) and Balaji fruit nursery, Ambekarwadi (07.22\%).

\section{At adult stage in main field}

The per cent disease incidence of dry root rot of sweet orange in adult stage in Aurangabad and Jalna district of Marathwada region was surveyed and data presented in Table 2.

The data (Table 2) revealed that the average mean per cent disease incidence of dry root rot was recorded in Jalna (20.49 \%) followed by Aurangabad (16.84\%).

In Aurangabad district the disease incidence was reported varied from 10.55 per cent to $26.66 \%$. 
Table.1 Per cent disease incidence of dry root rot of sweet orange nurseries in Jalna and Aurangabad districts

\begin{tabular}{|c|c|c|c|c|c|c|}
\hline $\begin{array}{l}\text { Sr. } \\
\text { No }\end{array}$ & District & & Name of nursery & $\begin{array}{l}\text { Availability } \\
\text { of no. of } \\
\text { plant }\end{array}$ & Variety & $\begin{array}{c}\text { Disease } \\
\text { incidence } \\
(\%)\end{array}$ \\
\hline \multirow[t]{5}{*}{1.} & \multirow[t]{5}{*}{ Jalna } & 1 & Govt. Nursery, Jalna & 20000 & $\begin{array}{l}\text { Nucellar, } \\
\text { Local }\end{array}$ & 10.5 \\
\hline & & 2 & $\begin{array}{l}\text { Govt. Nursery, } \\
\text { Wadigodari }\end{array}$ & 20000 & $\begin{array}{l}\text { Sathgudi, } \\
\text { Nucellar }\end{array}$ & 12.30 \\
\hline & & 3 & $\begin{array}{l}\text { Krushiraj fruit nursery, } \\
\text { Nagik Pangari }\end{array}$ & 12,000 & Local & 15.8 \\
\hline & & 4 & $\begin{array}{l}\text { Govt. Nursery, } \\
\text { Badnapur }\end{array}$ & 2385 & $\begin{array}{l}\text { Nucellar, } \\
\text { Local, } \\
\text { Sathgudi }\end{array}$ & 9.00 \\
\hline & & 5 & $\begin{array}{l}\text { Taluka Fruit nursery, } \\
\text { Mantha }\end{array}$ & $1,00,000$ & $\begin{array}{l}\text { Local, } \\
\text { Nucellar }\end{array}$ & 11.33 \\
\hline \multirow[t]{5}{*}{2.} & \multirow[t]{5}{*}{ Aurangabad } & 1 & $\begin{array}{l}\text { Balaji fruit } \\
\text { nursery,Ambekarwadi } \\
\text { (Taluka-Paithan) }\end{array}$ & 7,0000 & $\begin{array}{l}\text { Local, } \\
\text { Nucellar }\end{array}$ & 07.22 \\
\hline & & 2 & $\begin{array}{l}\text { Govt. fruit nursery, } \\
\text { Sillod }\end{array}$ & 10,000 & $\begin{array}{l}\text { Nucellar, } \\
\text { Local, } \\
\text { Sathgudi }\end{array}$ & 10.55 \\
\hline & & 3 & $\begin{array}{l}\text { Gajanan fruit nursery, } \\
\text { Pimpariraja }\end{array}$ & 75,000 & Local & 13.00 \\
\hline & & 4 & $\begin{array}{l}\text { Deepak fruit nursery, } \\
\text { Adul } \\
\text { (Taluka-Paithan) }\end{array}$ & $13,00,00$ & $\begin{array}{l}\text { Nucellar, } \\
\text { Local }\end{array}$ & 09.44 \\
\hline & & 5 & $\begin{array}{l}\text { Mohini fruit nursery, } \\
\text { Aurangabad }\end{array}$ & 20,000 & $\begin{array}{l}\text { Sathgudi, } \\
\text { Nucellar }\end{array}$ & 12.62 \\
\hline
\end{tabular}


Table.2 Per cent disease incidence of dry root rot of sweet orange in orchards at Aurangabad district

\begin{tabular}{|c|c|c|c|c|}
\hline Sr. No & District & Taluka & Village & Disease incidence $(\%)$ \\
\hline \multirow[t]{24}{*}{1} & \multirow[t]{27}{*}{ Aurangabad } & \multirow[t]{3}{*}{ 1) Aurangabad } & Shendra & 21.80 \\
\hline & & & Karmad & 17.30 \\
\hline & & & Ladsavangi & 26.66 \\
\hline & & \multirow[t]{3}{*}{ 2) Soegaon } & Fardapur & 18.70 \\
\hline & & & Naygaon & 25.60 \\
\hline & & & Wadi & 19.30 \\
\hline & & \multirow[t]{3}{*}{ 3) Sillod } & Lihakhedi & 11.20 \\
\hline & & & Mandana & 14.40 \\
\hline & & & Bodvad & 12.70 \\
\hline & & \multirow[t]{3}{*}{ 4) Kannad } & Bramhani & 20.50 \\
\hline & & & Dabhadi & 19.44 \\
\hline & & & Kolewadi & 17.10 \\
\hline & & \multirow[t]{3}{*}{ 5) khultabad } & Boodkha & 10.55 \\
\hline & & & Dhamni & 14.60 \\
\hline & & & Ghodegaon & 17.20 \\
\hline & & \multirow[t]{3}{*}{ 6) Gangapur } & Manjari & 18.70 \\
\hline & & & Wadgaon & 17.30 \\
\hline & & & Ambegaon & 22.60 \\
\hline & & \multirow[t]{3}{*}{ 7) Paithan } & Pimpalwadi & 17.70 \\
\hline & & & Baorgaon & 15.10 \\
\hline & & & Sulatanapur & 14.40 \\
\hline & & \multirow[t]{3}{*}{ 8) Phulambri } & Nimkheda & 14.21 \\
\hline & & & Bhoyagoan & 12.16 \\
\hline & & & Girsavali & 13.22 \\
\hline & & \multirow[t]{3}{*}{ 9)Vaijapur } & Narla & 14.10 \\
\hline & & & Shivagoan & 13.18 \\
\hline & & & Khirdi & 15.14 \\
\hline \multicolumn{4}{|c|}{ Average district mean } & 16.84 \\
\hline
\end{tabular}

Table.3(a) Mean of disease incidence in Tahsils of Aurangabad District

\begin{tabular}{|c|c|c|c|}
\hline Sr. No & District & Name of taluka & Mean per cent incidence \\
\hline $\mathbf{1}$ & & Jalna & 24.91 \\
\hline $\mathbf{2}$ & & Badnapur & 22.6 \\
\hline $\mathbf{3}$ & \multirow{3}{*}{ Jalna } & Bhokardan & 19.00 \\
\hline $\mathbf{4}$ & & Jafrabad & 19.54 \\
\hline $\mathbf{5}$ & & Ambad & 19.36 \\
\hline $\mathbf{6}$ & & Ghansavangi & 16.40 \\
\hline $\mathbf{n}$ & & Mantha & 24.23 \\
\hline $\mathbf{7}$ & & Partur & 17.93 \\
\hline
\end{tabular}


Table.3(b) Mean of disease incidence in Tahsils of Aurangabad District

\begin{tabular}{|c|c|l|c|}
\hline Sr. No & District & Name of taluka & Mean per cent incidence \\
\hline $\mathbf{1}$ & & Aurangabad & 21.92 \\
\hline $\mathbf{2}$ & & Soegaon & 21.20 \\
\hline $\mathbf{3}$ & & Sillod & 12.77 \\
\hline $\mathbf{4}$ & \multirow{3}{*}{ Aurangabad } & Kannad & 19 \\
\hline \multirow{5}{5}{} & & Khultabad & 14.12 \\
\hline $\mathbf{6}$ & & Gangapur & 19.54 \\
\hline $\mathbf{7}$ & & Paithan & 15.73 \\
\hline $\mathbf{8}$ & & Phulambri & 13.20 \\
\hline $\mathbf{9}$ & & Vaijapur & 14.14 \\
\hline & & & \\
\hline
\end{tabular}

Table.4 Per cent disease incidence of dry root rot of sweet orange in orchards at Jalna district

\begin{tabular}{|c|c|c|c|c|}
\hline Sr. No & District & Taluka & Village & $\begin{array}{c}\text { Disease incidence } \\
(\%)\end{array}$ \\
\hline \multirow[t]{21}{*}{2} & \multirow[t]{21}{*}{ Jalna } & \multirow[t]{3}{*}{ 1) Jalna } & Revagaon & 25.22 \\
\hline & & & Motigavhan & 24.60 \\
\hline & & & ManegaonKhalsa & 24.90 \\
\hline & & \multirow[t]{3}{*}{ 2) Badnapur } & Somthana & 20.50 \\
\hline & & & Warudi & 25.60 \\
\hline & & & Kandari & 21.70 \\
\hline & & \multirow[t]{3}{*}{ 3) Bhokardan } & Tandulwadi & 17.80 \\
\hline & & & Hasnabad & 19.22 \\
\hline & & & Nimgaon & 20.00 \\
\hline & & \multirow[t]{3}{*}{ 4) Jafrabad } & Kusali & 20.50 \\
\hline & & & Khanapur & 18.50 \\
\hline & & & Ambegaon & 19.60 \\
\hline & & \multirow[t]{3}{*}{ 5) Ambad } & Pimpalkhed & 21.30 \\
\hline & & & Naghzari & 17.55 \\
\hline & & & Khedgaon & 19.22 \\
\hline & & \multirow[t]{3}{*}{ 6) Ghansavangi } & Tirthapuri & 16.20 \\
\hline & & & Bahiregaon & 17.40 \\
\hline & & & Ukkadgaon & 15.60 \\
\hline & & \multirow[t]{3}{*}{ 7) Mantha } & Shirpur & 22.40 \\
\hline & & & Limbkheda & 24.60 \\
\hline & & & Jatkheda & 25.70 \\
\hline & & \multirow[t]{3}{*}{ 8. Partur } & Partur & 17.22 \\
\hline & & & Masla & 18.13 \\
\hline & & & Aakoli & 18.46 \\
\hline \multicolumn{4}{|c|}{ Average district mean } & 20.49 \\
\hline
\end{tabular}


However the maximum disease incidence noticed in in Ladsavangi $(26.66 \%)$ than other locations that surveyed. The disease prune areas reported were Naygaon (25.60\%), Ambegaon (22.60\%), Shendra (21.80\%) and Bramhani (20.50\%).

The lowest disease incidence was recorded at Boodkha $(10.55 \%)$ and at Lihakhedi (11.20 $\%)$ among all the locations surveyed.

In Jalna district the disease incidence of dry root rot was reported in the range of 15.60 to $25.22 \%$. However, higest disease incidence was noticed at Jatkheda $(25.70 \%)$ than the other locations that surveyed. This was followed by Warudi (25.60\%), Revagaon (25.22\%) Limbhkheda (24.60\%) and Motigavhan (24.60\%).

The lowest disease incidence was noticed at Ukkadgaon (15.60 \%) and Partur (17.22 \%) villages among all the orchards surveyed.

\section{Mean disease incidence}

The data from the (Table 3a) revealed that during this year, the mean disease incidence observed in eight tahasils of Jalna district ranged from 16.40 to 24.91 per cent. The highest mean disease incidence was found in Jalna tahasil (24.91) per cent. This was followed by Mantha (24.23\%), Badnapur (22.60\%), Jafrabad (19.54\%), Ambad (19.36\%), Bhokardan (19.60\%) and Partur tahasil $(17.93 \%)$. The lowest mean incidence was found in Ghansavangi (16.40\%).

It is revealed from the results of (Table $3 b$ ) that the mean disease incidence in different tahasils of Aurangabad district ranged from 12.77 to 21.92 per cent. The highest mean disease incidence was found in Aurangabad tahasil $(21.92 \%)$. This was followed by soegaon (21.20\%) Gangapur (19.54\%), Kannd (19.00\%), Paithan (15.73\%), Vaijapur
(14.14\%), Phulambri (13.20\%) and Kulthabad $(14.12 \%)$. The lowest disease incidence was reported in sillod tashil (Table 4).

The highest disease incidence in Jalna could be due to the presence of shallow, calcaroius soil with high soil $\mathrm{pH}$ which predisposes the trees to infection by pathogen, the same opinion was also expressed by Reddy and Paparao (1960), Reedy et al., (1999) and Gopal et al., (2000).

\section{References}

Ansar M, A. Saleem and K. Hameed (1994) Studies on cause of citrus of quick decline in the Punjab (Pakistan). Pakistan Journal of Phytopathology, 6: 38-40.

Bedi, K. S. (1961) The wilt disease of citrus nurseries. Punjab Horticulture Journal. 1: 141.

Bender, G. S., J. A. Menge, H. D. Ohr, and R. M. Burns (1982) Dry root-rot of citrus: it's meaning for the grower. Citrograph 67: 249-254.

Broadbent P. (2000) Dry root rot or sudden death. In: Timmer LW, Garnsey SM, Graham JH, editors. Compendium of citrus diseases. 2nd ed. St Paul (MN): APS Press. p.71.

Chenchu Reddy B, Govindarajula B, Aariff Khan M A and Hameedunissa Begum (1999) Root rot diseases the major cause of acid lime decline in Andhara Pradesh. Paper presented in International Symposium on Citriculture held at Nagpur, November 2327 at NRCC, Nagpur, India, 157.

Fawcett, H. S. (1936) Citrus diseases and their control. Mc Graw hill book Co Inc, New York, 97-100.

Ghosh R, S. Mamta, R. Telangre, S. Pande (2013) Occurrence and Distribution of Chickpea Diseases in Central and Southern Parts of India. American Journal of Plant Sciences, 4: 940-944.

Graham JH, Brlansky RH, Timmer LW, Lee RF, Marais, LJ, Bender GS. (1985) Comparison of Citrus tree declines with necrosis of major roots and their association with Fusarium solani. Plant Dis. 69:1055-1058. 
Gopal K, S. K. Ahammed, and P. Babu (2005) survey and screening of citrus root stocks against dry root-rot disease. Geobios 32 (4): 229-232.

Gopal K., M. R. S. Reddy, B. C. Reddy, A. R. Rao, M. Madhavi and K. T. Venkatraman (2000) Citrus decline in Andhara Pradeshcauses and their management. Paper presented in International symposium on Citriculture held at Nagpur, November 2327, (1999) at Nagpur, India, 107.

Herrera I. S., V. N. Valle, Gonzalez, V. N. Del Valle (1995) Fusarium solani (Mart) (Appell and Wr.) Snyd. and Hans, a causal agent of dry root-rot of citrus roots in Cuba. Centro Agicola 22(3): 76-78.

Kore. S. S. and A. V. Mane (1992) Dry root-rot of Kagzi lime seedlings caused by Fusarium solani Journal of Maharashtra agricultural University 17: 276-278.

Kore, S. S. and Mitkas (1993) Dry root-rot disease of pomegranate incited by Fusarium solani. Journal of Maharashtra Agricultural University 18 (2): 256-258.

Kumar Jeetendra (2014) Studies on survey of Fusarium wilt of pea in Eastern Uttar Pradesh Int. J. of Life Sciences, 2014, Vol. 2 (4): 359-362.

Lele, V. C., S. P. Rayachowdhari and ashram (1968) Dry root-rot of Trifoliate orange. A new nursery disease. Indian Phytopathology 21: 497-499.

Lio, G. M., S. G. Perrota and R. Tuttobene (1983) Research on pathogenic fungi present in the soil and Sour orange seedbeds in Sicily. Informants are Fitipathologicao 33:49-55.
Malikoutsaki et al., (1987) reported sever dry root-rot and Collar rot of citrus plants as well as seedling by Fusarium spp. from Greece.

Okamura JK, Davis RM. (1987) Latent and saprophytic fungal infections of grapefruit in south Texas. Texas $J$ Agric Nat Resources. 1:19-20.

Prakasam et al., (1992) reported the occurrence of dry root-rot disease in mandarin in Shevroy hills, caused by Fusarium spp.

Ramkrishnan T. S., (1954) The deterioration of mandarin orange in Madaras state. South India Horticulture 2: 52-56.

Reddy, G. S. and A. Papa Rao (1960) Problems of Sweet orange decline in Andhra Pradesh. Andhra Agricultural Journal 7: 175-188.

Srivastava H C and Singh B (1954) Seedling trouble in citrus beds and their control. Sci. Cult. 20:93-95.

Safdar A., Javed N, Khan S. A., Khan H.U., Rehman A. and Haq A.(2010) Survey and investigation of different citrus growing areas for citrus sudden death syndrome. Pak. J. Phytopathol., Vol 22(2):71-78.

Thaware D. S., Kohire O. D. and Gholve V. M. (2015) Survey of chickpea wilt (Fusarium oxysporum f.sp. ciceri) disease in Marathwada region of Maharashtra state. Advance Research Journal of Improvement volume 6: 134-138.

Vanderweyen and Serrihini (1981) Citrus dry root-rot in Morocco. Comptes-Rendusdesseances-de-1 Academie-d Agriculturede France 67: 1492-95.

\section{How to cite this article:}

Padvi, S.A., P.B. Khaire, V.H. Bhagat and Hingole, D.G. 2018. Survey on Incidence of Dry Root Rot of Sweet Orange in Aurangabad and Jalna District of Marathwada Region, India. Int.J.Curr.Microbiol.App.Sci. 7(07): 3677-3683. doi: https://doi.org/10.20546/ijcmas.2018.707.424 